\title{
National internationalism in late 19th-century utopias by Mór Jókai, Edward Bellamy, and William Morris
}

\section{SÁNDOR HITES}

DOI: https://doi.org/10.31577/WLS.2021.13.2.6

Intuitively, we expect utopias to offer salvation for the social, economic or political ills of the whole of humanity, and they usually appear to do so. ${ }^{*}$ Such was the case in the 19th century, which was the great era of modern utopianism, as well as the age of nationalism. Accordingly, many of its formative utopian narratives made their proposals for the reorganization of human communities in a peculiar double bind: while they intended to replace the layout of the nation-state, they remained captive to its conceptual framework.

Arguably, this dynamic was rooted in the early modern origins of the genre. As Phillip E. Wegner has pointed out, Thomas More's Utopia "reterritorialized" late feudal culture (in Deleuze and Guattari's well-known formulation) by inaugurating a "spatialized kind of political, social and cultural formation". Cut off artificially from the mainland, More's island (an idealized England) transforms "frontier" into "border" in a "disjunctive act of territorial inclusion as well as exclusion". This "new kind of spatiality" entails a "new kind of cultural identity" in which the sense of belonging stems from "the common habitation" of a territory, rather than religious allegiance or dynastic loyalty. This image of a community being congruent with the geographical space it occupies adumbrates the subsequent spatial practices of the modern nation-state, that is, the premise that the nation and its location should coincide. This connection between the "imaginary communities" of utopias and the "imagined communities" of nations, Wegner concludes, remains vivid throughout modernity, even if in the form of "estranging critique" (2002, 25-26, 49-60). Indeed, a great deal of the conflicts encoded in modern nationalism occurred precisely because of the inevitable incongruence of national communities and their state; as much as utopian spatial practice was imagined as national, the nationalistic politics of space has remained profoundly utopian.

This article will trace this dynamic in three novels by examining how the universalistic or internationalist tendencies in the utopian thought of the late 19th century were shaped, explicitly or tacitly, by the national or imperialistic imagination. Two of these works, Edward Bellamy's Looking Backward 2000-1887 (1888) and William Morris's News from Nowhere (1890), are firmly set in the core canon of utopian nar-

* The paper was written with the support of the "A 19. századi magyar irodalom politikai gazdaságtana" Lendület Research Program and is part of a wider project that looks at the economic ideas underlying 19th-century utopianism. 
ratives. The third, my chief concern here, The Novel of the Century to Come (A jövö század regénye, 1872-1874) written by Mór Jókai (1825-1904), arguably the most important Hungarian novelist of his age, is much less known outside its national canon. Compared to the formidable transnational impact of Looking Backward and News from Nowhere, manifesting early on in a great number of translations and, in Bellamy's case, a vast number of sales, Jókai's novel had a limited, albeit not fully negligible, international presence. As with most of Jókai's other works - including his biggest international success, The Gipsy Baron (A cigánybáró, 1885), which served as the inspiration for Strauss's operetta Der Zigeunerbaron - The Novel of the Century to Come was immediately translated into German (Jókai 1878). It appeared in two consecutive editions, one for the sizeable German-speaking audience in Hungary, the other directly for the German market (on Jókai’s German reception, see Ujvári 2011). Although some of Jókai's novels were also successful among Victorian-era English readers (see Magyar 1958), Century to Come never appeared in English.

Jókai's long and prolific career unfolded under the spell of Romantic nationalism, particularly the inspiration of such French Romantics as Eugène Sue, Alexandre Dumas père and Victor Hugo. His typical narrative formula placed exaggerated, larger-than-life characters into melodramatic plots, which he applied to various themes, most memorably historical parables celebrating early 19th-century Hungarian nation-builders or offering consolation for the failed revolution of 1848. From the late 1860s, Jókai became infatuated with industrial and technological progress and produced several novels, occasionally with themes and devices borrowed from Jules Verne, whose heroes utilized futuristic inventions in their nation-building missions (cf. Hárs 2019). One of these was The Novel of the Century to Come, an extremely long and eccentric book, even by its author's standards. Although generic hybridity is typical of utopian narratives, by attempting to encompass the full range of stock utopian themes Jókai's novel ends up with a nearly cacophonic mixture (on Jókai's utopianism in the context of Hungarian utopian traditions, see Czigányik 2015). Combining urbanistic utopia with "future history" and science fiction, mixing the sensationalist genres of Zukunftskrieg and financial fiction with the narrative devices of the adventure novel, Century to Come offers an eminent example of what Darko Suvin has called the "panoramic sweep" of utopian imagination (2010, 31-32): It engages with aspects of geography, demography, anthropology, history, religion, ethics, economics, politics, social and ethnic conflicts, warfare, technology, industry, ecology, astronomy, and cosmology.

Like other representatives of the transnational surge of utopian narratives after 1870, Jókai was inspired by two events: on the one hand, the Franco-Prussian War of 1871 and the Commune, on the other, the Panic of 1873 and the ensuing Long Depression. The former gave rise to a wave of "future-war fiction" (Clarke 1966), most memorably George T. Chesney's The Battle of Dorking: Reminiscences of a Volunteer (1871), whose innumerable imitations fed on British anxieties of a German or French invasion. Jókai's scenes of futuristic warfare reflect his fears, central to the Hungarian political imagination at the time, of a Pan-Slavic alliance under Russian leadership, fueled by still-recent memories of 1849 , when the tsarist army helped the Habsburgs 
to suppress the Hungarians; in Century to Come it is a "nihilistic" Russian empire, run by a group of anarchists, that invades a now peacefully united Austria-Hungary. With its intricate commercial and financial subplots, Jókai's novel also resonated with the "widespread perception" underlying the many works "permeated with anticipatory or utopian consciousness" between 1870 and 1900 that "capitalist society had arrived at some sort of historical turning point" (Beaumont 2005, 3). This perception, however, figured differently in different socio-economic environments: while American and British authors (including Bellamy and Morris) responded to the recurrent crises of mature industrial societies, Jókai reflected on the vicissitudes of the capitalist Gründerzeit in East Central Europe in general and in the Kingdom of Hungary in particular.

In Century to Come, the themes of warfare and finance are linked by the central motif of the novel, a miraculous technological invention. The electric airplane - designed by an autodidact Hungarian engineer, Dávid Tatrangi, exploiting a formerly unknown material, "ichor", only available in his native Transylvanian mountains revolutionizes both military confrontations and commercial relations. In Enlightenment thought, international trade had been associated both with the harmonious co-existence of nations (unified by their mutual needs and interests) and with self-destructive rivalries in a competitive and, as a tendency, imperialistic economic globalization (cf. Hont 2005; Kapossy, Nakhimovsky, and Whatmore 2017). Jókai plays out this controversial tradition, most directly, Kant's attempt to resolve the inherent conflicts of commercial sociability from a cosmopolitan perspective, by dividing his novel into two parts, "perpetual fight" and "perpetual peace". The invention of the airplane connects these phases in a dialectical pattern: escalating warfare to its ultimate destructive force, aviation eventually becomes the guardian of peace - driving commercial exchange to its ultimate extensity and intensity, it helps to unite nations by enforcing harmony and prosperity on them. Arguably, due to his authoritative notion of "mankind", Kant's cosmopolitan utopia of a world confederation of trading nations had its own nationalistic, Eurocentric and imperialistic moments (Biti 2016, 99-118). Jókai's vision of global harmony is also informed by a nationalistically defined internationalism, that is, a benevolent Hungarian military and commercial supremacy. ${ }^{1}$

A grotesque, and all the more typical, fantasy by the representative of a "minor nation" from the semi-peripheries of world politics and world economy. Yet one that resonates with the celebrated internationalisms of Bellamy and Morris inasmuch as these, I will argue, also derive from tacitly nationalistic or imperialistic imageries.

\section{RELOCATING THE NATION}

The utopian transformation of society relies on acts of relocation for Bellamy, Morris and Jókai alike. Bellamy's dream vision concentrates on urban centers, emblematically his futuristic Boston. Morris, in turn, disentangles human life from the city and relocates it in the countryside. In News from Nowhere, cities are either annihilated or deurbanized; Manchester, as we learn, "has now disappeared" (Morris 1995, 116), London is once again a place where rural lifestyles, architecture and vegetation prevail. Morris makes it central to his critique of Looking Backward that 
Bellamy "has no idea beyond existence in a great city" and degrades "the village" to be "mere servants of the great centers of civilization" (Morris 1889). Bellamy's and Morris's respective visions of a new social order correspond to these vectors of relocation (and both novels re-inscribe eliminated social inequalities into the hierarchy of locations). As opposed to the bureaucratized and centralized top-down state-socialism proposed in Looking Backward, in News from Nowhere the nation-state disintegrates into a loose network of communes. In spite of its collectivism, Bellamy's overcentralized world ends up in an even more atomized social design, comprised of nuclear families living in isolation and avoiding social encounters (Auerbach 1994, 29), while in Morris's ecological communism, autonomous households are interconnected by gestures of hospitality.

Although proclaiming social harmony, both novels are conspicuously saturated with images of war. For Bellamy, the reorganization of the state and the national economy rests on the peaceful militarism of the "industrial army". In Morris, it is not only political transformation that takes place in violent forms, revolution and civil war, but the subsequent reorganization of society is also described in tropes of aggression: "People flocked into the country villages, and, so to say, flung themselves upon the free land like a wild beast upon the prey" $(1995,74)$. The relocation of the population is carried out as a military campaign: As much as cities are reconquered for rural life, the movement in the opposite direction also takes the form of an "invasion", one in which "the town invaded the country". Society becomes fully re-ruralized when former town-dwellers adopt the peaceful lifestyle of the countryside, yet this process again unfolds in the style of militaristic expansion: "the invaders, like warlike invaders of early days, yielded to the influence of their surroundings, and became country people" (74). Jókai's narrative is also structured along multiple acts of relocation, spatial and temporal, geographical and historical. Century to Come begins with the utopian cityscape of 1950s Budapest, now the capital of a Hungary-dominated Austria-Hungary headed by a Hungaricized Habsburg dynasty which has abandoned Vienna for this new seat of power, the last stronghold of royalist sentiments in the empire. (Here Jókai plays out the ultimate political fantasy of post-1867 Hungarian politics, that of achieving hegemony within the dual monarchy.) At the beginning of the second part of the novel, that is, on the threshold of the transition from "perpetual struggle" to "perpetual peace", another city is raised through an even more profound act of relocation, that is, an exodus amounting to the second founding of the nation. After the great war in the first part of the novel, the remnants of the Hungarian army - de facto victorious over the invading Russian forces, but outmaneuvered diplomatically - are resettled in an uncultivated strip of land in the Danube Delta, purchased from the Russian state. Under the leadership of the inventor Tatrangi, this self-exiled community establishes a city-state designed along the stereotypical utopian blueprints of urbanistic planning, social engineering, and economic rationality.

This new country called Otthon (Home) hosts a thoroughly commercialized community. Transforming the Hungarian air force into a cargo fleet, they launch a commercial enterprise which, by virtue of their technological monopoly, comes 
to dominate global trade, "amassing wares from all parts of the world" in their "gigantic warehouses" (Jókai 1981a, 507). ${ }^{2}$ Formally, the new state is organized as a joint-stock company, with citizens as shareholders in a collective commercial enterprise: "We shall become a state that trades [...] a giant commercial firm. A shareholders' state, with an executive board at the top, which speculates and, based on its balance sheet, distributes dividends from the net profit and allocates reserve capital" (510).

In the design of Otthon, Jókai literalizes the trope that Bourdieu has called the "most fully developed form" of "utopian capitalism", that is, the myth of the "stockholder democracy" (Bourdieu 2005, 226). With the image that belonging to the community coincides with the collective ownership of a nation-scale company, congruent with the state itself, Jókai also anticipates Bellamy's scheme of reorganizing "the nation" into "one great business corporation in which all other corporation were absorbed" (Bellamy 2007, 33). It is also worth noting that while in Looking Backward the new structure of industrial society takes after the hierarchical model of the military, Jókai's utopian community grows out of a former army as it turns into a commercial republic thriving on world trade. Unlike, however, Bellamy's (and Morris's) vision, where the community is reorganized within the confines of its previous geographical location, Jókai's Otthon needs to carve out a space for itself in an unused and seemingly valueless land. The outskirts of this swamp are inhabited by "uncivilized" locals; we do not learn much about them after the new city has been built. With this, Jókai plays out "the myth of the empty land", widely employed in 19th-century colonialist imagination to conceal the founding violence of colonializing space (cf. McClintock 1995, 17). On the one hand, then, Otthon is tied up with a geographical space - and the novel explicitly associates its setting with former commercial republics built on water such as Holland and Venice - but its real location is the air, a sphere that it conquers for global commerce. As opposed to its geographical insularity, its hegemonization of the sky with its now commercial air fleet provides the new state with an all-encompassing, global reach.

Formed as a joint-stock company, citizenship in Otthon should be, by definition, limitless. Jókai's utopian city does have this cosmopolitan feature, yet it still remains an appendix to the motherland: it is mainly populated by subsequent waves of immigrants from Hungary. Not only is Hungarian the predominant language of Otthon, its commercial supremacy turns it into a global language. Because the air fleet of Otthon "carries most swiftly reliable news from all corners of the world" (Jókai 1981b, 21), everyone needs to learn Hungarian if they want to be able to read their newspapers and stay informed. Otthon also remains bound to Hungary by the relentless loyalty of Tatrangi (now the head of the executive board) to the sovereign. Although the center of power has shifted from Austria to Hungary, the novel nonetheless suggests that the rise of Otthon retrospectively compensates for the trade posts that Austria lost in the 18th century, traditionally blamed for the fact that the empire had been excluded from the main currents of world trade and commercial wealth in Western Europe. With this gesture, Jókai integrates this essentially Hungarian enterprise into the whole of Habsburg imperial history. 
The other aspect of historicizing this utopian "home" is more decidedly national. The relocation of the best of the nation into a commercial outpost - geographically remote and conceptually utopian - performs a "second Conquest" (the first refers to the arrival of the Hungarian tribes from the Asian steppes to the Carpathian basin in the late 9th century). And this "second Conquest" takes place not only in a spatial but also in a temporal sense. Wandering through the Far East in his airplane, Tatrangi happens to discover the lost Hungarian aboriginal tribe (the myth of which was and has remained a permanent obsession of the Hungarian historical consciousness), living in their own secluded yet highly advanced utopian community in the Himalayas. (For an analysis of this mise-en-abyme utopia-within-utopia in the novel, see Hajdu's article in this issue.) Tatrangi transports them on his air fleet over to the new state, thereby uniting the prehistorical ancestry of the nation with its futuristic offspring. Otthon, an idealized fatherland in exile, thus becomes the place where the Ur-Space of the nation can be discovered and reconnected with, reunifying the nation both geographically and historically.

The fantasy that Hungarian prehistory sheds its mythical mist and reenters world history does not merely solve a riddle of national historiography but has universal relevance. It is with the help of the lost tribe that Tatrangi's air fleet can defeat the Russians for the second time and usher in the era of "perpetual peace". That is, mankind can only be unified after the unity of the Hungarian nation and the continuity of its history have been restored (Szilágyi 2008). For what makes Otthon destined for the task of imposing universal peace and prosperity is that, as Jókai underlines, Hungary is the only nation that is at home in Europe as well as in Asia. The commercial republic of Otthon can carry out its mission to "form a center connecting the commerce of Europe and Asia and expand its network over all the continents of the world and all their islands" (Jókai 1981a, 501) by utilizing the event of world-historical significance in which "the two brother-nations, once split apart, now reunited again [...] grow into an ore colossus, with one leg set in the center of Europe, the other in that of Asia" (Jókai 1981b, 160). Thus, the Hungarian commercial republic turns into a Hungarian commercial empire, overarching East and West, imposing its benevolent dominance on the world and even more, a cosmic harmony: The novel ends with a Fourieresque vision in which the gravitational force of a comet passing by the Earth's atmosphere straightens the globe's tilted axis, and, rebounding from the Sun, just as Tatrangi has predicted in his astronomical calculations, introduces a new planet into the solar system.

\section{NATIONALISMS AND IMPERIALISMS}

With his grandiose vision conflating historical mythology and modern commercialism, Jókai manages to reconcile the historicist notion of nationhood with the felt cosmopolitanism and anti-historicity of capitalism, and to fuse the (alleged) rationality of utilitarian values with the heroism of romantic nationalism.

Such aspirations are seemingly alien to Bellamy or Morris. First of all, the patterns of temporality they foreground in their work are different: while Jókai futurizes historical memory by infusing its national myths into commercial and technological cap- 
italism, Bellamy's industrial society is forged by the "theoretical rejection" of memory, Morris's by the revival of a markedly pre-capitalist past (Geoghegan 1992). Nevertheless, Bellamy and Morris were no less enmeshed in controversial negotiations between universalistic and national perspectives. This is even so concerning their respective efforts of de-historicization and historicization: the cult of novelty in Looking Backward universalizes the myth of America's blank past; the communistic medievalism of Nowhere marks a return to a national Anglo-Saxon past. Thus, whether encoded in its future (Bellamy), in its past (Morris), or in the mythological fusion of the two (Jókai), all three authors claim transnational relevance for their respective nations.

The term "Nationalism" in Looking Backward signals the communal propertization and concentration of resources and means of production and distribution. By choosing a word that had the connotations of isolationism and autarky rather than international collaboration, Bellamy wanted to distance his ideas from those of European socialists (Matarese 1989, 44-45). Still, he envisioned a global social and economic transformation in which, not unlike in Jókai's fantasy, his own nation would take the lead and other nations would follow suit: "[T] he great nations of Europe as well as Australia, Mexico, and parts of South America, are now organized industrially like the United States, which was the pioneer of the evolution" (Bellamy 2007, 82). In his first draft of the novel, Bellamy recalled, "the United States was supposed to be merely an administrative province of the great World Nation", directed from the city of Berne (Bellamy 1889). By opting to replace this scheme with that of American leadership, Bellamy chose to universalize what he preferred to see as genuinely American features. It might be argued that this "messianic nationalism" is counterbalanced by "the book's insistent internationalist message" which came to resonate widely in transatlantic socialist circles (Guarneri 2008, 147-151, 166-168). Yet it is precisely the way in which Looking Backward outlines transnational cooperation that is saturated by the sense of supremacy: "An international council regulates the mutual intercourse and commerce of the members of the union and their joint policy toward the more backward races, which are gradually being educated up to civilized institutions" (Bellamy 2007, 82).

Although it is centralized state-socialism that he upholds as a paradigm to be imitated globally, Bellamy's scheme of social evolution follows the same logic which, in Bourdieu's view, came to propel the 20th century globalization of market liberalism: both universalize "the historical particularities of a particular social tradition - that of American society" by postulating this tradition and its "civic and ethical" ideals "as an inevitable destiny" and "the end-point of a natural evolution" which "promises political emancipation for the peoples of all countries" (Bourdieu 2005, 226). Bellamy's cooperative socialism and the American ideology of market democracy also coincide insofar as both collapse into consumerism. The expectation of the values of a "post-national US nationalism" to spread globally is predicated on a form of cosmopolitanism that takes its model from Roman imperialism (cf. Arendt 2017, 165-171; Biti 2016, 171-173). And as it has been demonstrated, the American utopian imagination, including Bellamy's, did inform American foreign policy in the 20th century (Matarese 2001). 
In News from Nowhere, Morris markedly distances himself from any sense of nationalism, treating nationalistic ideas, or the very concept of nation, with nothing but scorn. Pacifying appeals to the "common mother', the English Nation" during the period of the civil war are revoked as characteristically reactionary gestures (Morris 1995, 126). In Morris's view, "modern nationalities" were "artificial devices for the commercial war", and a post-capitalist world would entail their dissolution insofar as they functioned solely by and for the purpose of capital accumulation: "When profits can no more be made there will be no necessity for holding together masses of men to draw together the greatest proportion of profit to their locality, or to the real or imaginary union of persons and corporations which is now called a nation" (cited in Holland 2017, 196-197).

The concept that nations are locations of capital plays a more positive role, in fact a constitutive one, in Century to Come. While Morris's new England is a society which has "long ago dropped the pretension to be the market of the world" (1995, 70), Jókai's ideal state aspires precisely to become the "market of the world" thereby fulfilling its world-historical mission. As a trading post outsourced from the "mother nation", Otthon is raised on the vast profits it makes in global trade. More precisely, it is created for the purpose of making profit because only by adding commercial wealth to its military might (and intellectual and technological superiority) can it reach the position from which it can efficiently pacify the world. The task is not to "destroy commercialism" as in Morris $(1995,135)$ but to transform it into a benevolent world-unifying force.

In proposing this, Jókai was clearly inspired, however indirectly, by the British free trade movement (that is, the doctrines of Richard Cobden and the Manchester industrialists) and its slogans of international peace, cooperation and social justice secured by laissez-faire commercial exchange (Trentmann 1998). Under the reign of Otthon's commercial air fleet, we learn, "systems of protective tariffs and customs zones collapse" as they become untenable and meaningless (Jókai 1981b, 29). But as Tatrangi insists, unhindered trade can only exert its benign influence if in its dominance of "intermediating between continents" Otthon does not turn into a black hole of capital, but "lets the profits of international commerce spread across the world" (14). That is, the credo of free trade can only be realized by an uncontested force which at the same time has the ethical conviction to understand the stakes of this mission. Unlike Bellamy and Morris, what Jókai offers is not a socio-economic alternative to global capitalism but a moral reform of its existing structures. International commerce may turn into an agency of peace and prosperity if this process is installed and supervised from the position of ultimate power and humanism. This mission cannot be entrusted to the logic of history or the self-regulation of the market but remains the competence of an individual, the inventor, pilot and head of state Tatrangi, who, in addition to his superhuman qualities, remains an essentially national hero.

In the British free trade movement and its proclaimed anti-imperialism - from the perspective of the aggressive foreign policy with which it proved reconcilable, merely another form of imperialism (Semmel 1970) - Morris saw an instance of "false internationalism" which aligned itself with the "international character of capital", seek- 
ing profit "wherever it can be best found" (Holland 2017, 185, 189-190). Morris's ideal of a socialist internationalism rested on the brotherhood of men with no national affiliation. Nonetheless, News from Nowhere is conspicuously reticent about political, social and economic structures beyond Britain as Morris "limits his description [of the effects of the revolution] to the confines of a single nation-state" (Crump 1990, 68). When Guest asks Old Hammond whether other parts of the world have undergone the same social transformation, and, if so, whether life has not become dull without the competition of nations, he is offered the enigmatic advice to "cross the water and see" (Morris $1995,88)$. Showing little concern toward wider regions of the world in the utopian future, Morris seems to have adopted Bellamy's restricted focus and also seems to have replicated his bias for national exceptionalism. For Bellamy, it is the collective wisdom of American society that makes a rational choice of self-reform which then spreads across the globe. For Morris, it is the British labor movement and its revolution that installs the new social system, to be followed elsewhere (as he hints, in continental Europe, though not in North America). As much as it is the English civil war that brings "the world" to "its second birth" (135), it is again an immanent tendency in national social history that is endowed with world-historical or universal relevance.

Furthermore, it also remains ambivalent how the new, communistic Britain would relate to its former colonies or to regions of the world that are still open to be colonized. As Owen Holland's illuminating analysis has shown, in spite of Morris's "internationalist and anti-imperialist political rhetoric", News from Nowhere does not rule out the possibility of colonial engagements in a future socialist society (Holland 2017, 23, 227-237). As Old Hammond remarks, "[we] have helped to populate other countries [...] where we wanted and were called for" (Morris 1995, 76), "[t]hose lands which were once the colonies of Great Britain [...] and especially America [...] are now and will be for a long while a great resource to us" (101). This suggests that while Britain as a nation-state is superseded, the structure of colonial exploitation (and the positions of center and periphery, "us" and "them", hardly reconcilable with the image of a decentered socialist internationalism) would persist. In fact, Morris had already insisted on "fertilising the waste places of the earth" in his 1887 article 'Emigration and Colonisation' where he also stressed that "the Roman idea of leading a colony is right and good", and "the society of the future" would continue "to send out some band of its best and hardiest people to socialise some hitherto neglected spot of earth for the service of man" (cited in Holland 2017, 230-231).

\section{THE ENDURING LEGACY OF "PATRIOTIC COSMOPOLITANISM"}

Jókai's commercial utopia redeeming the world in a Pax Hungarica reflects national anxieties and aspirations which are typical of the political fantasies cherished in the semi-periphery. His nationally informed or biased internationalism, however, points to a deeper, underlying pattern that also determines, as we saw in the case of Bellamy and Morris, the utopian imagination of "core nations".

This pattern, I would suggest in conclusion, might be traced back to the legacy of enlightened cosmopolitanism. Prior to the rise of modern nationalism, a "universally normative concept of culture" could remain weltbürgerlich even if it was "iden- 
tified with the culture of a certain ethnolinguistic people" (Cheah 1998, 25-26). This sense of patriotic cosmopolitanism, in which patriotism is taken as the highest form of cosmopolitanism, can be witnessed in the political philosophy of Johann Gottlieb Fichte. If human Bildung reaches an advanced stage in one nation, and this nation happens to be one's own, then why not wish to expand it all over to others - Fichte asks in his 1806-1807 dialogue "Der Patriotismus und sein Gegenteil". As he expounds, given their exceptional aptitude for science and philosophy Germans are entitled to the world historical mission of spearheading the progress of reason in all mankind. Accordingly, only Germans may legitimately wish to impose their findings on all humanity. Or, in other words, "only Germans can be patriots" and "embrace humanity" in the same gesture; other patriotisms, as a rule, are "selfish, narrow-minded, and hostile to the rest of the human race" (Fichte 1971, 233-234).

I would by no means suggest that the Fichtean reconciliation of universalism and patriotism had a direct influence on the authors discussed in this article. What I do suggest though is that a similar pattern tacitly informed their negotiations of national and international perspectives. However paradoxical it may sound to us, it was surely not paradoxical to Fichte, and, apparently, its self-contradictions proved resolvable, consciously or subconsciously, for Jókai, Bellamy and Morris as well.

\section{NOTES}

1 The idea that the advancement of aviation would enforce states to abandon warfare harks back to Benjamin Franklin's contemplations about air balloons in the 1780s. A similar concept of securing peace by dominating the air resurfaced in H.G. Wells's 1933 The Shape of Things to Come and its vision of an Anglophone "Air Dictatorship" (cf. Kapossy, Nakhimovsky, and Whatmore 2017, 7-8). Jókai's scheme is nearly identical with Wells's, except that for him it is the Hungarian domination of the air that ushers in the era of global peace. On Jókai's involvement in the international peace movement of the late 19th century, see Kovács 2016.

2 This and all subsequent translations from the Hungarian (unless otherwise noted) are by the present author.

\section{LITERATURE}

Arendt, Hannah. 2017. The Origins of Totalitarianism. New York, NY: Penguin Classics.

Auerbach, Jonathan. 1994. “'The Nation Organized': Utopian Impotence in Edward Bellamy's 'Looking Backward"' American Literary History 6, 1: 24-47. DOI: https://doi.org/10.1093/alh/6.1.24.

Beaumont, Matthew. 2005. Utopia Ltd.: Ideologies of Social Dreaming in England 1870-1900. Leiden and Boston, MA: Brill.

Bellamy, Edward. [1888] 2007. Looking Backward 2000-1887, ed. by Matthew Beaumont. Oxford: Oxford University Press.

Bellamy, Edward. 1889. "How I Came to Write 'Looking Backward”' The Nationalist, May 1889. Accessed May 1, 2021. https://www.depauw.edu/sfs/documents/bellamy.htm.

Biti, Vladimir. 2016. Tracing Global Democracy: Literature, Theory, and the Politics of Trauma. Berlin and Boston, MA: de Gruyter. DOI: https://doi.org/10.1515/9783110457643.

Bourdieu, Pierre. 2005. The Social Structures of the Economy. Trans. by Chris Turner. Cambridge and Malden, MA: Polity Press. 
Cheah, Pheng. 1998. "Introduction Part II: The Cosmopolitical - Today." In Cosmopolitics: Thinking and Feeling Beyond the Nation, ed. by Pheng Cheah and Bruce Robbins, 20-41. Minneapolis, MN and London: University of Minnesota Press.

Clarke, Ignatius F. 1966. Voices Prophesying War: Future Wars 1763-1984. Oxford: Oxford University Press.

Crump, John. 1990. "How the Change Came: 'News from Nowhere' and Revolution." In William Morris \& News from Nowhere: A Vision for Our Time, ed. by Stephen Coleman and Paddy O'Sullivan, 57-73. Hartland, MI: Green Books.

Czigányik, Zsolt. 2015. "From the Bright Future of the Nation to the Dark Future of Mankind: Jókai and Karinthy in Hungarian Utopian Tradition." Hungarian Cultural Studies 8: 12-23. DOI: https://doi. org/10.5195/ahea.2015.213.

Fichte, Johann Gottlieb. 1971. "Der Patriotismus und sein Gegenteil." In Fichtes Werke, Band XI. Vermischte Schriften aus dem Nachlaß, ed. by Immanuel Hermann Fichte, 221-274. Berlin: Walter de Gruyter \& Co.

Geoghegan, Vincent. 1992. “The Utopian Past: Memory and History in Edward Bellamy's Looking Backward and William Morris's News from Nowhere." Utopian Studies 3, 2: 75-90.

Guarneri, Carl J. 2008. "An American Utopia and Its Global Audiences: Transnational Perspectives on Looking Backward." Utopian Studies 19, 2: 147-187.

Hajdu, Péter. 2021. “Mór Jókai’s Asian Utopia(s).” World Literature Studies 13, 2: 56-68.

Hárs, Endre. 2019. "LiterarischeSumpflandschaften. Technischer Fortschritt und Naturgestaltung bei Mór Jókai (1825-1904)." Hungarian Studies 33, 1: 115-134. DOI: https://doi.org/10.1556/044.2019.33.1.8.

Holland, Owen. 2017. William Morris's Utopianism: Propaganda, Politics and Prefiguration. London: Palgrave Macmillan. DOI: https://doi.org/10.1007/978-3-319-59602-0.

Hont, Istvan. 2005. Jealousy of Trade: International Competition and the Nation-State in Historical Perspective. Cambridge, MA, and London: Harvard University Press.

Jókai, Maurus. 1878. Der Roman des künftigen Jahrhunderts. In acht Büchern. Vol. 1-2. Preßburg and Leipzig: Carl Stampfel.

Jókai, Mór. 1981a. A jövő század regénye (1872-1874). Vol. 1, ed. by Zsuzsa D. Zöldhelyi. Budapest: Akadémiai.

Jókai, Mór. 1981b. A jövő század regénye (1872-1874). Vol. 2, ed. by Zsuzsa D. Zöldhelyi. Budapest: Akadémiai.

Kapossy, Béla, Isaac Nakhimovsky, and Richard Whatmore. 2017. "Introduction: Power, Prosperity, and Peace in Enlightenment Thought." In Commerce and Peace in the Enlightenment, ed. by Béla Kapossy, Isaac Nakhimovsky, and Richard Whatmore, 1-19. Cambridge: Cambridge University Press. DOI: https://doi.org/10.1017/9781108241410.001.

Kapossy, Béla, Isaac Nakhimovsky, and Richard Whatmore, eds. 2017. Commerce and Peace in the Enlightenment. Cambridge: Cambridge University Press. DOI: https://doi.org/10.1017/9781108241410.

Kovács, Henriett. 2016. “Zwei Zukunftsbilder des ewigen Friedens in Österreich-Ungarn. Bertha von Suttner und das utopische Maschinenalter - Mór Jókai und der satirische Roman des künftigen Jahrhunderts." In Literarischer Pazifismus und pazifistische Literatur. Bertha von Suttner zum 100. Todestag, ed. by Johann Georg Lughofer and Stéphane Pesnel, 147-162. Würzburg: Verlag Königshausen \& Neumann.

Magyar, Francis. 1958. “Jókai's Reception in England and America." American Slavic and East European Review 17, 3: 332-345.

Matarese, Susan M. 1989. "Foreign Policy and the American Self Image: Looking Back at Looking Backward." American Transcendental Quarterly 3, 1: 45-54.

Matarese, Susan M. 2001. American Foreign Policy and the Utopian Imagination. Amherst, MA: University of Massachusetts Press.

McClintock, Anne. 1995. Imperial Leather: Race, Gender and Sexuality in the Colonial Contest. London: Routledge.

Morris, William. 1889. "Looking Backward." Transcribed by Ted Crawford. Commonweal 5, 180: 194195. Accessed May 1, 2021. https://www.marxists.org/archive/morris/works/1889/commonweal/ 06-bellamy.htm. 
Morris, William. [1890] 1995. News from Nowhere, or an Epoch of Rest: Being Some Chapters from a Utopian Romance. Ed. by Krishan Kumar. Cambridge: Cambridge University Press.

Semmel, Bernard. 1970. The Rise of Free Trade Imperialism: Classical Political Economy, the Empire of Free Trade and Imperialism 1750-1850. Cambridge: Cambridge University Press.

Suvin, Darko. 2010. "Defining the Literary Genre of Utopia: Some Historical Semantics, Some Genology, a Proposal, and a Plea (1973)." In Defined by A Hollow. Essays On Utopia, Science Fiction and Political Epistemology, Darko Suvin, 17-48. Bern: Peter Lang.

Szilágyi, Márton. 2008. "Habsburg-Utopie und Habsburg-Mythos am Ende des 19. Jahrhunderts, Maurus Jókai, Der Roman des künftigen Jahrhunderts.” In Kulturtransfer und Kulturelle Identität: Budapest und Wien zwischen Historismus und Avantgarde, ed. by Károly Csúry, Zoltán Fónagy, and Volker Munz, 197-206. Szeged and Vienna: Szegedi Egyetemi Kiadó and Praesens Verlag.

Trentmann, Frank. 1998. "Political Culture and Political Economy: Interest, Ideology and Free Trade." Review of International Political Economy 5, 2: 217-250.

Ujvári, Hedvig. 2011. Kulturtransfer in Kakanien. Zur Jókai-Rezeption in der deutschsprachigen Presse Ungarns (1867-1882). Berlin: Weidler Buchverlag.

Wegner, Phillip E. 2002. Imaginary Communities: Utopia, the Nation, and the Spatial Histories of Modernity. Berkeley, Los Angeles, CA, and London: University of California Press.

\title{
National internationalism in late 19th-century utopias by Mór Jókai, Edward Bellamy, and William Morris
}

Nation-building. Capitalism. Relocation. Literary pacifism. Commerce. Imperialism. Mór Jókai. Edward Bellamy. William Morris.

The paper looks at two major representatives of fin-de-siècle utopian fiction, Edward Bellamy's 1888 Looking Backward 2000-1887, William Morris's 1890 News from Nowhere, and an earlier work by the Hungarian novelist Mór Jókai, The Novel of the Century to Come (A jövö század regénye, 1872-1874). I examine their various strategies regarding the spatial and historical aspects of utopian transformation as well as their respective positions toward the relation of commerce and community. On the whole, I suggest that the pattern of nationally informed or biased internationalism that seems to underlie all three novels might be traced back to the enlightened concept of patriotic cosmopolitanism.

\author{
Sándor Hites \\ Research Center for the Humanities \\ Institute of Literary Studies \\ 11-13 Ménesi út. \\ 1118 Budapest \\ Hungary \\ hites.sandor@abtk.hu
}

